\title{
Agroedutourism Model to Improve Environmental Awareness of Students in Some Elementary School in Malang Raya, East Java
}

\author{
Hanin Niswatul Fauziah ${ }^{1^{*}}$, Endang Arisoesilaningsih ${ }^{2}$, Bagyo Yanuwiadi ${ }^{2}$ \\ ${ }^{1}$ Department of Education, State Islamic College of Ponorogo, Indonesia \\ ${ }^{2}$ Department of Biology, Faculty of Mathematics and Natural Sciences, University of Brawijaya, Malang, Indonesia
}

\begin{abstract}
This research aimed to build specific agroedutourism model for elementary school students in Malang Raya. Target of this research were 5th grade students from SDN Ketawanggede 2, SDN Sumberngepoh 02 and SDI Surya Buana. We provided three agroedutourism programs, there were 1). Learning on farmer's friends and enemies, 2). Learning on plants as raw material for biopesticide and natural attractant and 3). Learning on healthy agroecosystem. Each agroedutourism program was composed by discussion, eco-games and taste of healthy foods. Data obtained by distributing questionnaires and analyzed by open source software, Smart PLS (Partial Least Square). Agroedutourism model from PLS output showed that learning on farmer's friends and enemies program was the most effective to improve cognitive competence, enjoyment, pleasure, and the final-understanding of elementary school students than the other programs. While, initial-understanding directly contributing to improve cognitive competence and finalunderstanding of elementary school students. Cognitive competences directly influence to improve the student's appraisal of foods that were obtained. Student enjoyment directly influence to affection and appreciation. Based on those models, to improve final-understanding, we had to improve initial-understanding using learning on farmer's friends and enemies program. Students' appreciation was improved by improving affection and appreciation.
\end{abstract}

Keywords: agroedutourism, appreciation, cognitive, environmental awareness.

\section{INTRODUCTION}

Environmental quality influenced by the condition of the environment, better condition of environment can make a better quality of it. However, nowadays the condition of the environment is really bad, most people were degrading the environment instead of conserve it $[1,2]$. The increased of population, natural resources exploitation, technology developments, economic, social activities without notice to carrying capacity of the environment can caused some problem for the environmental, such as soil degradation, flooding, air pollution, global warming, and depletion of ozone $[3,4,5]$. Considering the various environmental problems that occur, efforts are needed to improve the understanding on the importance of environmental conservation.

In Indonesia, efforts to improve understanding on the importance of environmental conservation have long programmed, either through formal or informal education. In formal education, on February 19, 2004 the Ministry of Environment in collaboration with the Ministry of National Education and Ministry of Religious

\footnotetext{
${ }^{*}$ Correspondence address:

Hanin Niswatul Fauziah

Email : haninhusein@gmail.com

Address : Tarbiyah Departmen, State Islamic College of Ponorogo, Jl. Pramuka 156, Ponorogo, 63471.
}

Affairs to establish a policy of Environmental Education (EE) which is used as a base or direction for all stakeholders involved in the implementation of environmental education in Indonesia. However, efforts to prevent and resolve environmental problems are less rapidly with actions which cause environmental degradation. As a result, environmental problems still occur and develop into uncontrolled, so Environmental Education system has not succeeded in forming human environmental awareness. Formal environmental education in elementary school was still not optimal to improve students understanding on environmental awareness due to the theoretical materials, not discussing the real problems and had not involved local people participation [6]. It can lead to less attention on environmental education than economy aspect. As a result, environmental problems still occur, due to the most of environmental problems caused by human activities to get their needs [7]. Therefore, it is necessary for environmental education to also pay attention on environmental conservation and economic of society, thus environmental education is able to realize the sustainable development.

Sustainable development is development that meets the needs of the present without compromising the ability of future generations to meet their own needs [8]. One of the efforts to realize 
sustainable development is by tourism $[9,10]$. Tourism is expected to increase the economy while conserve the cultural and the environment. Due to Indonesia is an agricultural country and most of the population are farmers, thus the type of tourism that used is agricultural tourism (agrotourism). Agrotourism is integrated system and coordinated activities for the development of agricultural tourism in relation to environmental conservation. Agrotourism provides many benefits, both of farmers, local communities and visitors. For farmers and local communities agrotourism is an alternative to explore the economic potential and to increase income. For visitors, agrotourism can improve knowledge, experience, recreation, and businesses in agriculture [11]. By development of agrotourism that highlight local culture in land use, we can increase farmers' income while conserve land resources, local culture and technology (indigenous knowledge) were generally suitable with their natural environment conditions [12]. The agrotourism is packaged into educational tourism based on agriculture (agroedutourism = agriculture education and tourism) which used for Environmental Education.

One of the areas in East Java that has potential as an agroedutourism is Malang. This educational tourism based on agriculture (agroedutourism) is packed with game models thus it is suitable for elementary school students [13]. Game is one of the effective methods for teaching children [14], by playing the childrens expected to learn well due to the relaxe learning atmosphere and the application of environmental education from early age will be embedded within them that will affect their life style. This research aimed to build specific agroedutourism model for elementary school students in Malang Raya. This information is expected to provide an alternative environmental education for elementary students.

\section{MATERIALS AND METHODS}

Targets of this research were the $5^{\text {th }}$ grade students from SDN Sumberngepoh 02, SDN Ketawanggede 2 and SD Islam Surya Buana. The $5^{\text {th }}$ grade students selected as agroedutourism target due to they began to be sensitive to environmental conditions and have been able to express their opinions [15]. Furthermore, the implementation of environmental education from elementary school will be embedded within them. Students in one class devided into three groups and one group only got one agroedutourism program. Each agroedutourism program had duration of 150 minutes. We provided three agroedutourism as follows.

\section{Farmer's Friends and Enemies Program}

Students were invited to rice field and given the first questionnaire to determine the cognitive, affective and appreciation of the students before the implementation of agroedutourism program. After finishing first questionnaire, student received agroedutourism leaflet.

Furthermore, students learn about organic farming and the dangers of pesticides and synthetic chemical fertilizers application from undergraduate student and learn about farmer's friends and enemies from farmer. During the study, students are stimulated to ask about the lessons that have been taught. In this agroedutourism program, students are also invited to observe animals in the rice fields. Animals that were found recorded and identified their role (as a farmer's friend or enemy) with farmer help. After agroedutourism implementation had been done, students were invited to taste the foods and drink; i.e. brownies bran, zalacca fruits and red rice milk. And then, the students received the second questionnaire. It was used to determine cognitive competence, affection, appreciation, enjoyment and pleasure that the question based on agroedutourism program. Furthermore, students got eco-game called "guess predator and prey and guess the name and animals function on the farm". After it, the students were given the final questionnaire, to determine the cognitive, affective and appreciation after the implementation agroedutourism program.

\section{Plants as Raw Material for Biopesticide and Natural Attractant Program}

Students were invited to school yard and given the first questionnaire to determine the cognitive, affective and appreciation of the students before the implementation of agroedutourism program. After finishing first questionnaire, student received agroedutourism leaflet. Furthermore, students learn about organic farming, the danger of synthetic chemical pesticides and fertilizers application, learning the plants that can be biopesticides and attractant farmer's friend from undergraduate student. Lesson about plants for biopesticides and natural enemies' attractant given by taking samples of the plants later explained their name and function. After implementation of agroedutourism program had been done, students were invited to taste the foods and drink; brownies bran, zalacca fruits and 
red rice milk. Then the students received the second questionnaire, it was used to determine cognitive competence, affection, appreciation, enjoyment and pleasure that the question based on agroedutourism program. Furthermore, students got eco-game called "guess the name and function of plants around us". After it, the students were given the final questionnaire, to determine the cognitive, affective and appreciation after the implementation agroedutourism program.

\section{Healthy Agroecosystem Program}

Students still in the class, furthermore they were given the first questionnaire to determine the cognitive, affective and appreciation of the students before the implementation of agroedutourism program. After finishing first questionnaire, student received agroedutourism leaflet. Furthermore, undergraduate student and teacher explained about Indonesia farming system, the danger of synthetic chemical pesticides and fertilizers application and its solution. After implementation of agroedu-tourism program had been done, students were invited to taste the foods and drink; brownies bran, zalacca fruits and red rice milk. Then the students received the second questionnaire, it was used to determine cognitive competence, affection, appreciation, enjoyment and pleasure that the question based on agroedutourism program. Furthermore, students got eco-game called "playing snakes and ladders and learning rice farming environment". After it, the students were given the final questionnaire, to determine the cognitive, affective and appreciation after the implementation agroedutourism program.

\section{Data Analysis}

Questions type in the questionnaire were open ended question, closed ended question and close reasoned question. Those questionnaire using scoring system, the question that has two answers were scored 1-2, question that has five answers were scored 1-5 while open-ended questions were scored 1-5. To determine agroedutourism model, the variables of program was analyzed on initial understanding (questionnaire 1), final understanding (questionnaire 3), cognitive competence, enjoyment, pleasure, affection and appreciation (questionnaire 2) by open source software, Smart PLS (Partial Least Square).

\section{RESULT AND DISCUSSION}

The theoretical model from the literature was initial understanding affect on cognitive competence, affection, appreciation and final understanding of elementary school students. While, the agroedutourism program affect to cognitive competence, enjoyment, pleasure, affection, appreciation, and final understanding of elementary school students. Cognitive competence affect to enjoyment, pleasure, affection, appreciation and initial understanding of elementary school students. Enjoyment affect to pleasure, affection and appreciation for elementary school students. Pleasure affect to affection and appreciation for elementary school students. The affection and appreciation affect to final understanding of elementary school students (Fig. 1). Those theoretical model would used as the basic for modeling in PLS.

Outer loading result indicate that the indicator of 3 cognitive competencies (knowledge to control pests, the differences between chemical pestiside and biopesticides and nutrient of rice) in the cognitive competencies variable and the indicator of pleasure 2 (appraisal on organic red rice milk flavor) in the pleasure variable had t-statistics value $<1.96$. It showed that latent variables of cognitive competence represented by cognitive indicators 1 and 2 while the pleasure represented by pleasure indicator 1 , thus the cognitive indicators 3 and pleasure indicator 2 should be excluded from the model. After those indicators were excluded from the model, model was rearranged and the results showed that all indicators adequate validity convergent. The model validity from the calculation of predictive relevance $\mathrm{Q}_{2}$ value was $96.94 \%$. It means that $96.94 \%$ of elementary school students' final understanding influenced by initial understanding, program, cognitive competence, enjoyment, pleasure, affection and appreciation, while $3.06 \%$ was influenced by the other variables that were not in the model. Those model validity more than $80 \%$, thus it feasible to use.

The result of models analysis for improvement students' cognitive competence showed that initial understanding directly improve the cognitive competence and final understanding (Fig. 2). It means that, the higher of students' initial understanding made the cognitive competence and final understanding students will be higher as well. The research result showed that SDN Sumberngepoh 02 students who had the highest initial understanding had the higher 
cognitive competence and final understanding as well. While SDI Surya Buana students who had low initial understanding had low cognitive competence and final understanding as well. Therefore, to improve cognitive competence and final understanding, the students' initial understanding should be improved first. This initial understanding was obtained from their environments, such as family and school. SDN Sumberngepoh 02 students got knowledge about organic farming from their family who worked as farmers and they fre-quently help their parents work in the rice fields. While SDI Surya Buana students did not come from farming families, so they had less know-ledge about organic farming.

Therefore, to improve students' initial understanding, education on the importance of organic farming need included in school lesson, such as Natural Sciences. While the student's initial understanding did not directly influence the affection and appreciation. It means that, affection and appreciation can be formed without initial understanding. Learning on farmer's friends and enemies program was the most effective to improve enjoyment, pleasure, cognitive competence and final understanding than the other program. While learning on healthy agroecosystem program was the least effective to improve the four variables than the other program. Therefore, learning on plants as raw material for biopesticide and natural attractant and learning on healthy agroecosystem should be improved on the lesson and teaching methods. There were presumption that learning on farmer's friends and enemies were agroedutourism program that directly related to the object being studied. Students were invited at the rice fields to identify the animals name and their functions.

Learning on healthy agroecosystem program is a virtual agroedutourism, the students learn in the classroom and not contact with the object being studied, so the students only imagine the object studied. Previous research results indicated that learning achievement of Biology (Arthropods lesson) class $X$ which used natural animals was higher than used the image [16]. It showed that learning which use natural objects more effective to improve learning achievement compared to learning which use artificial object. In addition, students more interested to follow the learning farmer's friends and enemies program than learning on plants as raw material for biopesticide and natural attractant program. It is due to this program implemented in rice field which was a new location for students to learn, while the others program that implemented in the school. Students less interested following agroedutourism program in the school due to the school was a student daily place to learn so the students who follow agroedutourism program in the school want to learn in the environment such as in the rice fields. Interesting will support the enjoyment, pleasure, cognitive competence and final undersatanding of students. Interest was one of the factors that influence the success of teaching and learning program [17]. To get good final result of an activity, someone should have a high interest in advance.

Cognitive competencies directly improve the student appraisal of the foods that were provided. The high of students' knowledge for organic red rice and rice bran benefit would make students appraisal of the food that were provided. Therefore, to improve students' appraisal of 'brownies rice bran and organic red rice milk, the students' knowledge for the benefit of these foods should be improved. Previous research found that knowledge of elementary school students to foods nutrients influence the students behavior in choosing snacks that they bought [18]. Students that knew the benefits of food nutrition prefer to healthy snack and had a high nutrition than the less healthy snack.

Enjoyment variable directly improve student affection to the environmental conservation. Students who enjoy following agroedutourism program will have the higher affection than the students who less enjoy the program. It was expected that students will have the higher environmental awareness than students who were less enjoy following agroedutourism program. It was consistent with Marhaeni research which states that enjoyment was one of the affective factors that influence the achievement of students in learning English [19].

Based on the model (Fig. 2) was known that affection directly improve the appreciation. People who had high affection on environment would have a better appreciate to conserve the environment. Affection is one of the factors that influence the appreciation [20]. Based on the model, to improve the students' final understanding, students' initial understanding should be improved and agroedutourism program that used was learning on farmer's friends and enemies program. Students appreciation improved by increased affection and pleasure. 
Agroedutourism Model to Improve Environmental Awareness of Students (Fauziah et al.)

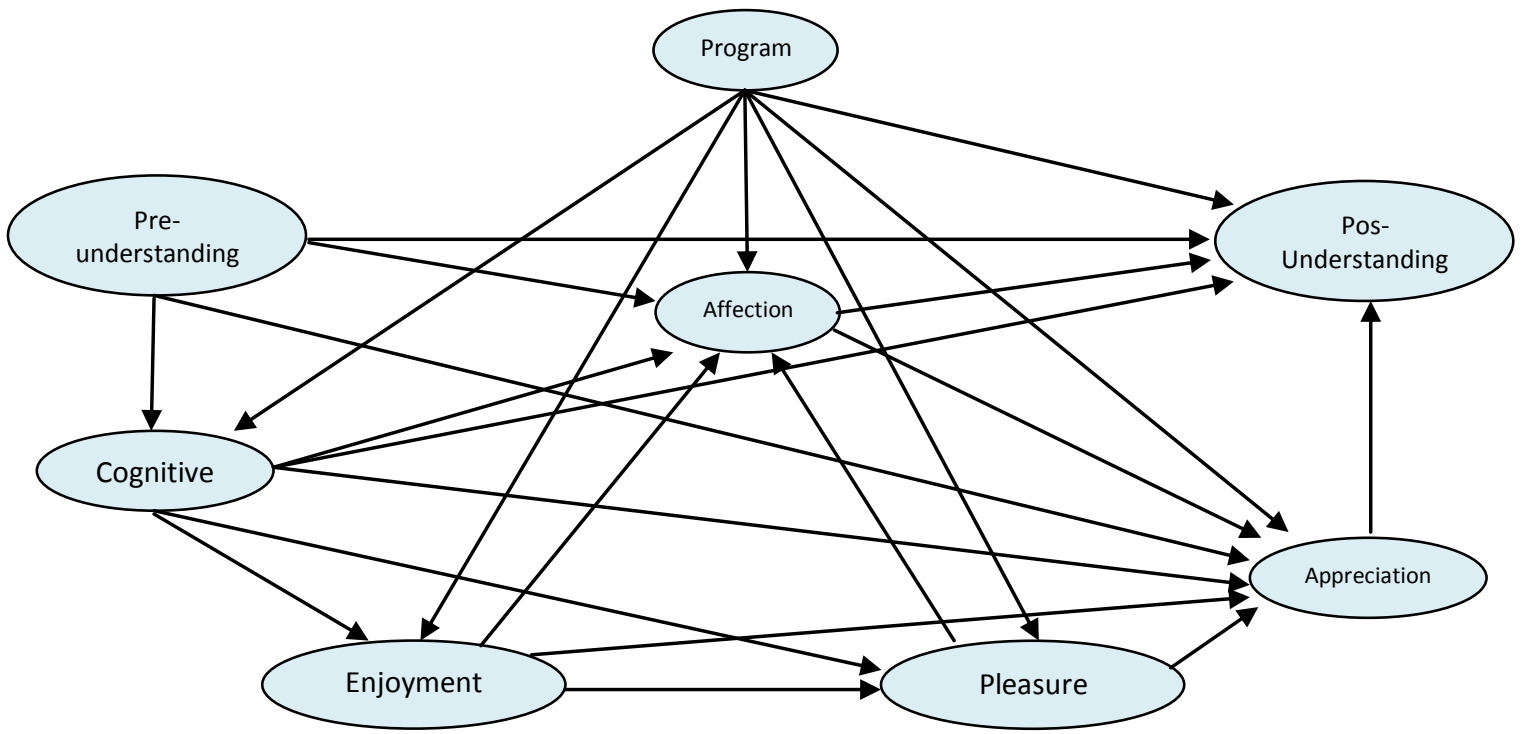

Figure 1. The Theoretical Model of Improvement Students' Competence of Agroedutourism Participant

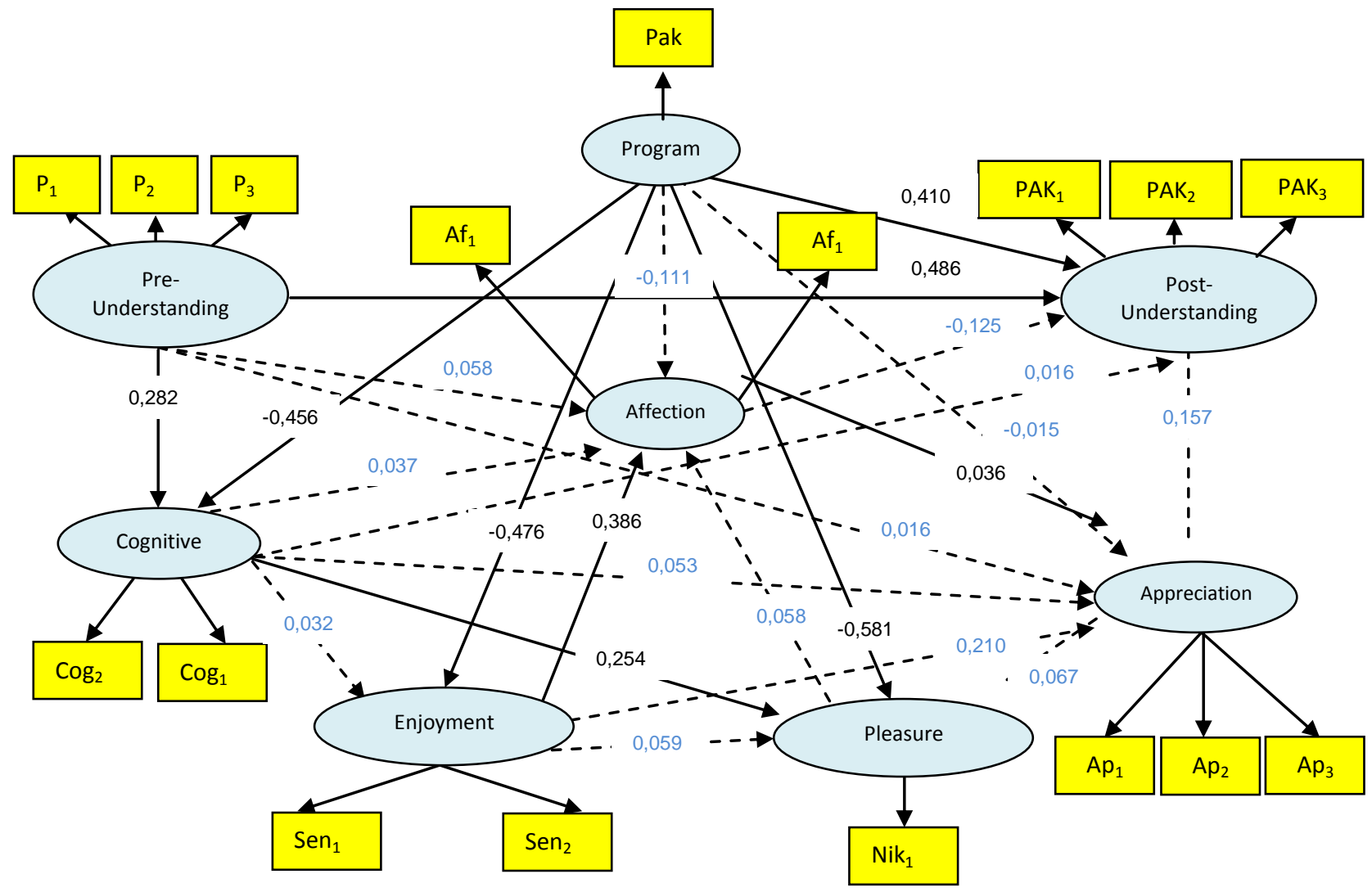

Figure 2. Model of Improvement Students' Competence of Agroedutourism Participant

Description: $\longrightarrow$ (directly influnced, black value); $-\rightarrow$ (indirectly influenced, blue value); $\bigcirc=$ laten variable; $\square$ dicator. $P_{1,2,3}=$ initial understanding $1,2,3 ; \operatorname{Cog}_{1,2}=$ cognitive competence 1,2; $\operatorname{Sen}_{1,2}=$ enjoyment1,2; $\mathrm{Nik}_{1}=$ pleasure 1; $\mathrm{Ap}_{1,2,3}=$ Apreciation 1,2,3; $\mathrm{Af}_{1,2}=$ Affectioni 1,2; $\mathrm{PAK}_{1,2,3}=$ final understanding 1,2,3.

\section{CONCLUSION}

Learning on farmer's friends and enemies program was the most effective to improve cognitive competence, students' enjoyment, appraisal of the foods that were provided and final understanding of elementary school students than the other program (learning on plants as raw material for biopesticide and natural attractant and learning on healthy agroecosystem). Otherwise, initial understandings directly improve cognitive competence and final understanding of elementary school students. Cognitive competence directly influenced by apparaisal of the foods that were provided. Enjoyments 
improve the students' affection and appreciation to the environmental. The weakness of this study was each student only receives one agroedutourism program, therefore needed study on the effectiveness of all agroedutourism programs on the final understanding of student with varied parental background.

\section{ACKNOWLEDGEMENT}

I would like to express gratitude to Dr. Endang Arisoesilaningsih for funding this research, SDN Ketawanggede 2, SDN Sumberngepoh 02 and SDI Surya Buana for supporting this research.

\section{REFERENCES}

[1] Yuniato, B. 2012. Building citizen awareness of environmental conservation.International Journal of Scientific \& Technology Research 1(7), 87-89.

[2] Akhter, S. and P. Malaviya. 2015. Assesment of environmental awareness among rural and urban resident in Bishnah, Jammu and Kashmir, India. International Journal of Basic and Applied Sciences 4(3), 180-182.

[3] Huong, H. 1999. Environmental policies and natural resource management in Southeast Asia. Global Nest 1(3), 217-225.

[4] Islam, N. 2008. Public awareness about environmental issues: perspective Bangladesh. Asian Affairs 30(2), 30-56.

[5] Ogunjinmi, A. A., S. A. Onadeko, and A. A. Adewumi. 2012. An empirical study of the effects of personal factors on environmenttal attitudes of local communities around Nigeria's Protected Areas. The Journal of Transdisiplinary Environmental Studies 11(1), 40-53.

[6] Setiawan, I. 2011. Upaya mewujudkan pembangunan berkelajutan melalui pendidikan lingkungan hidup. Available at: http://file.upi.edu/Direktori/FPIPS/JUR._PE ND._GEOGRAFI.

[7] Stern. 2000. Toward a coherent theory of environmentally significant behavior. Journal of Social Issues 56(3), 407-424.

[8] Becker, J. 2005. Measuring progress towards sustainable developmnet: an ecological framework for selecting indicator. Local Environment 10(1), 87-101.

[9] UNCSD NGO Steering Committee. 1999. Tourism and sustainable development. Available at:http://www.gdrc.org/uem/ecotour/ngo4.pdf.

[10] Wu, C. W. 2009. Sustainable development conceptual framework in tourism industry context in Taiwan: resources based view. Conference of International Journal of Arts and Sciences 2(1), 1-11.

[11] Sasanti, S.A., F. Ananda and M. Fadli. 2011. Pengembangan agrotourism berbasiskan ramah lingkungan dalam peningkatan kesejahteraan masyarakat, diversifikasi pangan dan penerapan pertanian modern di Desa Muntuk, Kecamata Dlingo, Kabupaten Bantul. Scientific Paper PKM. Bogor Agricultural University. Bogor.

[12] Departmnet of Agriculture. 2005. Agrowisata meningkatkan pendapatan petani. Available at: http://pustaka.litbang.deptan. go.id/publikasi/wr241029.pdf.

[13] Setyarini, S. 2010. Puppet show: inovasi metode pengajaran bahasa inggris dalam upaya meningkatkan kemampuan berbicara siswa. Jurnal Penelitian Pendidikan 11(1), 1-7.

[14] Widyastuti, S. 2010. Belajar sambil bermain: metode mendidik anak secara komunikatif. Seminar of Child Education. Teruna Bangsa School. Klaten.

[15] Telie, A. S. 2004. Pemberian paket indera dan pengaruhnya terhadap sikap anak pada alam. Jurnal Psikologi Sosial 13(1), 50-64.

[16] Yulius. 2005. Pengaruh pemanfaatan gambar dan hewan asli dalam pembelajaran materi Arthropoda melalui pendekatan kontekstual terhadap hasil belajar siswa kelas $\mathrm{X}$ SMA Negeri 1 Muara Batu Kabupaten Aceh Utara. Thesis. Department of Biology Education, Malang State University. Malang.

[17] Sucihatiningsih, D. W. P. and H. Sulistyowati. 2006. Faktor-faktor yang mempengaruhi kesulitan belajar mata pelajaran IPS Ekonomi. Jurnal Pendidikan Ekonomi Dinamika Pendidikan 1(2),162-181.

[18] Najihah, U. 2011. Hubungan pengetahuan gizi dan jumlah uang saku dengan perilaku siswa dalam memilih makanan jajanan di SD Muhammadiyah 2 Kauman Surakarta. Thesis. Department of Nutrition. Surakarta Muhammadiyah University. Surakarta.

[19] Marhaeni, A. A. I. N. 2008. Determinasi beberapa faktor afektif yang mempengaruhi keberhasilan belajar mahasiswa jurusan pendidikan bahasa inggris Universitas Pendidikan Ganesha. Jurnal Pendidikan dan Pengajaran UNDIkSHA 3(41), 733-755.

[20] Sageofasheville. 2012. Carl Rogers and humanistic education. Available at: http://www.sageofasheville.com/. 